\title{
Beers-Fick criteria and drugs available through the Farmácia Dose Certa program
}

\author{
Critérios de Beers-Fick e medicamentos disponíveis no Programa Farmácia Dose Certa
}

\author{
Giancarlo Lucchetti', Alessandra Lamas Granero Lucchetti", Sueli Luciano Pires"I", Milton Luiz Gorzoni"
}

Geriatrics and Gerontology Sector, Santa Casa de São Paulo, São Paulo, Brazil

KEY WORDS:

Aged.

Pharmaceutical preparations.

latrogenic disease.

Adverse effects.
Drug prescriptions.

\begin{abstract}
CONTEXT AND OBJECTIVE: Farmácia Dose Certa is a program available in the State of São Paulo that is a national reference for providing drugs free of charge to the population. Elderly people receiving care deserve special attention regarding drugs that are appropriate for their age group. The objective was to assess the drugs in the program considered to be inappropriate for the elderly.

DESIGN AND SETTING: Descriptive study evaluating free drug distribution in the State of São Paulo, Brazil.

METHODS: Following the criteria proposed by Beers and Fick (drugs or drug classes that should be avoided among elderly people, independent of the diagnosis or clinical condition, because of the high risk of side effects and because other, safer drugs are available), the drugs in the Farmácia Dose Certa program that might be inappropriate for elderly people and the levels of evidence for each drug included were assessed.

RESULTS: Among the available drugs, 10 (25.6\%) were included within the Beers-Fick criteria. The drugs selected were: amitriptyline, cimetidine, diazepam, digoxin, fluoxetine, methyldopa, nifedipine, promethazine, thioridazine and ferrous sulfate.

CONCLUSION: The list of drugs available within the Farmácia Dose Certa program may be considered appropriate for the general population, but not completely for the elderly population. Adjusting this list to the pharmacological aspects of aging will reduce the risks of drug interactions, falls, mental confusion and excessive sedation that result from drugs that are considered inappropriate for consumption by elderly people.
\end{abstract}

\section{RESUMO}

\section{Idoso.}

Preparações farmacêuticas.

Prescrições de medicamentos.

Doença iatrogênica.

Reações adversas a

medicamentos.

\begin{abstract}
CONTEXTO E OBJETIVO: Programa Dose Certa é programa estadual para disponibilizar medicamentos de forma gratuita à população do Estado de São Paulo que é referência nacional no assunto. 0 segmento de idosos na população assistida merece atenção especial quanto aos fármacos adequados a este segmento etário. 0 objetivo foi avaliar as drogas no programa que são impróprias para idosos. TIPO DE ESTUDO E LOCAL: Estudo descritivo avaliando a distribuição de medicamentos no estado de São Paulo.

MÉTODOS: Seguindo-se os critérios propostos por Beers e Fick (medicamentos ou classes deles que deveriam ser evitados em idosos, independentemente do diagnóstico ou da condição clínica, devido ao alto risco de efeitos colaterais e pela existência de outros fármacos mais seguros), avaliaram-se quais medicamentos do programa Dose Certa são impróprios para idosos e os níveis de evidência para cada medicamento incluído.

RESULTADOS: Dos medicamentos disponíveis, 10 (25,6\%) foram incluídos nos critérios de Beers-Fick: amitriptilina, cimetidina, diazepam, digoxina, fluoxetina, metildopa, nifedipina, prometazina, tiorodazida e sulfato ferroso.

conclusão: A lista de fármacos disponível no Programa Dose Certa pode ser considerada apropriada para a população em geral, mas não totalmente para idosos. Adequá-los a aspectos farmacológicos do envelhecimento reduzirá riscos de interações medicamentosas, quedas, confusão mental e sedação excessiva decorrente de medicamentos considerados impróprios para o consumo de idosos.
\end{abstract}

\section{INTRODUCTION}

Approximately 14.5 million Brazilians are elderly (8.6\% of the total Brazilian population). ${ }^{1}$ Over the past four decades, there has been a twofold increase in the rate of aging in this country, and the segment of the population aged 60 years or more has grown fastest. ${ }^{2} \mathrm{Be}-$ cause elderly people suffer from more chronic and degenerative diseases, they usually consume more drugs and, consequently, can suffer more adverse effects than seen in the general population. ${ }^{3}$ This can be explained by the physiological changes relating to aging, such as body composition and renal and hepatic function, which alter the pharmacokinetics and pharmacodynamics of various drugs. ${ }^{4}$

With the aim of defining which groups of medications are potentially inappropriate for the elderly, Beers ${ }^{5}$ established criteria for this. These were later upgraded by Fick et al. ${ }^{6}$ and bring together a list of drugs or drug classes that should be avoided among the elderly, regardless of the diagnosis or clinical condition, because of the high risk of adverse effects and/or the existence of safer drugs. Following this normative standard, we sought to determine what percentage of potentially inappropriate drugs available in the Farmácia Dose Certa pro-

'MD. Geriatrics specialist, Geriatrics and Gerontology Sector, Santa Casa de São Paulo, São Paulo, Brazil. "MD. Geriatrics specialist, Interdisciplinary Center for Aging Research and Care, Belo Horizonte, Minas Gerais, Brazil.

'I'MD, MSc. Professor of Geriatrics and Director of Hospital Dom Pedro II, Geriatrics and Gerontology Sector, Santa Casa de São Paulo, São Paulo, Brazil.

${ }^{\mathrm{I}} \mathrm{MD}, \mathrm{PhD}$. Professor and head of Geriatrics and Gerontology Sector, Santa Casa de São Paulo, São Paulo, Brazil. 
gram (a reference program for dispensation of medicines free of charge in the State of São Paulo) met the Beers-Fick criteria.

\section{OBJECTIVE}

The objective was to assess the drugs in the program that are considered to be inappropriate for the elderly.

\section{METHODS}

This study consisted of an analysis on which drugs available through the Farmácia Dose Certa program of the São Paulo State Health Department met the Beers-Fick criteria.

The drugs available within the Farmácia Dose Certa program were obtained from the following sites: http://portal.saude.sp.gov.br and http://www.furp.sp.gov.br/dose_certa/dose.asp. These drugs are available without charges for the entire population of São Paulo, Brazil.

The inclusion criteria used by the present study were based on the Beers criteria, as modified by Fick et al. ${ }^{6}$ in 2003 . These criteria were initially developed by Beers ${ }^{5}$ in 1997, through a consensus involving prominent people in the fields of geriatrics, pharmacology and psychopharmacology who had done an extensive review of scientific studies available at that time. In 2003, Fick et al. ${ }^{6}$ reviewed and updated these criteria (Table 1).

Table 1. Criteria for potentially inappropriate medication use among older adults independent of diagnoses or conditions. ${ }^{6}$ Only drugs available in Brazil are displayed

\begin{tabular}{|c|c|}
\hline Benzodiazepines & Amiodarone \\
\hline Lorazepam > 3.0 mg/day & Digoxin $>0.125 \mathrm{mg} /$ day \\
\hline Alprazolam > $2.0 \mathrm{mg} /$ day & (except in atrial arrhythmias) \\
\hline Chlordiazepoxide & Disopyramide \\
\hline Diazepam & Methyldopa \\
\hline Clorazepate & Clonidine \\
\hline Flurazepam & Nifedipine \\
\hline Amitriptyline & Doxazosin \\
\hline Fluoxetine (daily) & Dipyridamole \\
\hline Barbiturates (except phenobarbital) & Ticlopidine \\
\hline Thioridazine & Non-steroidal anti-inflammatory \\
\hline Meperidine & Indomethacin \\
\hline Anorexic drugs & Naproxen \\
\hline Amphetamines & Piroxicam \\
\hline Antihistamines & Muscle relaxants and antispasmodics \\
\hline Chlorpheniramine & Carisoprodol \\
\hline Diphenhydramine & Chlorzoxazone \\
\hline Hydroxyzine & Cyclobenzaprine \\
\hline Cyproheptadine & Orphenadrine \\
\hline Tripelennamine & Oxybutynin \\
\hline Dexchlorpheniramine & Hyoscyamine \\
\hline Promethazine & Propantheline \\
\hline Chlorpropamide & Belladonna alkaloids \\
\hline Non-associated estrogens (oral) & Ketorolac \\
\hline Thyroid extract & Ergot and cyclandelate \\
\hline Methyltestosterone & Laxatives \\
\hline Nitrofurantoin & Bisacodyl \\
\hline Ferrous Sulfate & Cascara sagrada \\
\hline Cimetidine & Mineral Oil \\
\hline
\end{tabular}

Since then, the Beers-Fick criteria have been used in population studies to analyze administrative data in intervention studies and regulation of drugs for nursing homes. They are also used to assess prescription patterns, medical education, clinical outcomes, costs and use of public health services. ${ }^{6}$ The criteria are divided as follows: ${ }^{6}(1)$ drugs or drug classes that should generally be avoided for people over 65 years of age, because they are ineffective or have a high risk or unnecessary adverse effects when a safer alternative is available; and (2) medications that should not be used for elderly patients with specific known conditions.

We analyzed all 65 drugs listed in the Farmácia Dose Certa program of the State of São Paulo. We decided to exclude 13 antibiotics from the analysis because they were not used on a regular basis; two drugs in the form of creams; five oral contraceptives because of their predominant use in younger age groups; a salt for oral rehydration used among children; and two vitamins. Drugs that had more than one presentation were considered as only one drug (there were three such drugs). For each drug available through the Farmácia Dose Certa program and included in the Beers-Fick criteria, we decided to show the level of evidence regarding higher number of adverse reactions in elderly individuals, compared with non-elderly individuals (Table 2 ).

The evidence for each drug was based on data from the Oxford Centre for Evidence-based Medicine (http://www.cebm.net). The levels of evidence were classified as follows: 1. systematic review (SR) of randomized controlled trials (RCTs) or an individual RCT; 2. cohort studies (CS) or SR of CS, or "outcomes" research or ecological research; 3. case-control studies (CCS) or SR of CCS; 4. case series or poor-quality cohorts or poor-quality CCS; and 5. expert opinion without explicit critical appraisal.

\section{RESULTS}

Out of the 65 drugs, 26 were excluded because they fulfilled the exclusion criteria, as described in the Methods. The final list was composed of 39 drugs. From these, 10 (25.6\%) were included within the Beers-Fick criteria, particularly the antihypertensive and psychotropic drugs (antipsychotics, benzodiazepines and antidepressants) (Table 2). The following drugs were included as potentially inappropriate: amitriptyline, cimetidine, diazepam, digoxin, fluoxetine, methyldopa, nifedipine, promethazine, thioridazine and ferrous sulfate. The level of evidence for each drug included is shown in Table 2. The percentages of drugs classified as appropriate or inappropriate according to the BeersFick criteria were divided into groups according to the recommendations of the National List of Essential Medications (Relação Nacional de Medicamentos Essenciais; Rename) $)^{7}$ and are summarized in Table 3.

\section{DISCUSSION}

The Farmácia Dose Certa program is a national reference program that has been providing free drugs to the general population since $1995 .{ }^{8}$ According to the program website, by the year 2008, 14.5 billion drug doses had been exempted from charges for the São Paulo population since its beginning. 
Table 2. List of drugs provided by the Farmácia Dose Certa program in São Paulo, reasons for inappropriateness for the elderly according to the Beers-Fick criteria ${ }^{6}$ and levels of evidence for inclusion

\begin{tabular}{|c|c|c|c|}
\hline Available drugs & Reason to be inappropriate & Level of Evidence & References \\
\hline \multicolumn{4}{|l|}{ Aspirin $100 \mathrm{mg}$ and $500 \mathrm{mg}$ tablet } \\
\hline \multicolumn{4}{|l|}{ Acid Valproic $250 \mathrm{mg}$ tablet } \\
\hline \multicolumn{4}{|l|}{ Aminophylline $100 \mathrm{mg}$ tablet } \\
\hline \multicolumn{4}{|l|}{ Biperiden $2 \mathrm{mg}$ tablet } \\
\hline \multicolumn{4}{|l|}{ Captopril $25 \mathrm{mg}$ tablet } \\
\hline \multicolumn{4}{|l|}{ Carbamazepine $200 \mathrm{mg}$ tablet } \\
\hline Cimetidine $200 \mathrm{mg}$ tablet & Central nervous system side effects including mental confusion & 4 & $18,19,20$ \\
\hline \multicolumn{4}{|l|}{ Clomipramine 25 mg caplet } \\
\hline \multicolumn{4}{|l|}{ Clonazepam $2 \mathrm{mg}$ tablet } \\
\hline \multicolumn{4}{|l|}{ Chlorpromazine 25 mg tablet } \\
\hline \multicolumn{4}{|l|}{ Chlorpromazine $100 \mathrm{mg}$ tablet } \\
\hline Diazepam $10 \mathrm{mg}$ tablet & Long half-life, prolonged sedation, increase risk of falls and fractures & 2 & $21,22,23$ \\
\hline \multicolumn{4}{|l|}{ Phenytoin $100 \mathrm{mg}$ tablet } \\
\hline \multicolumn{4}{|l|}{ Phenobarbital $100 \mathrm{mg}$ tablet } \\
\hline Fluoxetine $20 \mathrm{mg}$ tablets/caplets & $\begin{array}{l}\text { Long half-life, can lead to overstimulation of the central nervous } \\
\text { system, sleep disorders and excessive agitation }\end{array}$ & 5 & $6,27,28^{*}, 29 *, 30^{*}$ \\
\hline \multicolumn{4}{|l|}{ Furosemide $40 \mathrm{mg}$ tablet } \\
\hline \multicolumn{4}{|l|}{ Glibenclamide $5 \mathrm{mg}$ tablet } \\
\hline \multicolumn{4}{|l|}{ Haloperidol $5 \mathrm{mg}$ tablet } \\
\hline \multicolumn{4}{|l|}{ Hydrochlorothiazide 25 mg tablet } \\
\hline \multicolumn{4}{|c|}{ Aluminum hydroxide $62 \mathrm{mg} / \mathrm{ml}$ oral suspension } \\
\hline \multicolumn{4}{|c|}{ Imipramine $25 \mathrm{mg}$ caplet } \\
\hline Methyldopa $250 \mathrm{mg}$ film-coated tablet & May cause bradycardia and exacerbate depression in older patients & 5 & $31,32,33^{*}, 34^{*}$ \\
\hline \multicolumn{4}{|l|}{ Propranolol $40 \mathrm{mg}$ tablet } \\
\hline Salbutamol $2 \mathrm{mg} / 5 \mathrm{ml}$ syrup & & & \\
\hline Sertraline $50 \mathrm{mg}$ tablet & & & \\
\hline Ferrous sulfate drops & Doses above $325 \mathrm{mg} /$ day may increase constipation & 5 & 6 \\
\hline Thioridazine $100 \mathrm{mg}$ tablet & Great potential for central nervous system and extrapyramidal effects & 5 & 6 \\
\hline
\end{tabular}

Levels of Evidence: 1. Systematic review (SR) of randomized controlled trials (RCTs) or individual RCT; 2. Cohort studies (CS) or SR of CS or "outcome" research or ecological research; 3. Case-control studies(CCS) or SR of CCS; 4 . Case series or poor-quality cohorts or poor-quality CCS; and 5. Expert opinion without explicit critical appraisal

* Studies showing no differences in adverse events, in comparison with other drugs.

Table 3. Appropriate and inappropriate drugs according to the Beers-Fick criteria, ${ }^{6}$ divided into groups according to the National List of Essential Medications (Relação Nacional de Medicamentos Essenciais) ${ }^{8}$ and available through the Farmácia Dose Certa program

\begin{tabular}{lcccc}
\hline Drug class or group & Appropriate & Inappropriate & Total & Percentage of inappropriate drugs \\
\hline Antiallergics & - & 1 & 1 & 1 \\
\hline Antiulcer drugs & - & 1 & 1 & $100.0 \%$ \\
\hline Inotropes & - & 1 & 1 & $100.0 \%$ \\
\hline Antidepressants & 2 & 2 & 4 & 5 \\
\hline Antihypertensives & 3 & 2 & 5 & $50.0 \%$ \\
\hline Anti-anxiety drugs & 2 & 1 & 3 & $40.0 \%$ \\
\hline Anticonvulsants & 4 & - & 4 & $33.3 \%$ \\
\hline Hypoglycemic drugs & 2 & - & 2 & $0.0 \%$ \\
\hline
\end{tabular}


The drugs chosen for the program were selected because they were essential for use in primary healthcare. New drugs can be included or existing drugs can be excluded, within the scope of the program and according to the demand from primary healthcare units.

In 1995, when the program was first implemented, $7.2 \%$ of the population of Brazil was 60 years of age or over. Within this context, the Farmácia Dose Certa program was designed for younger age groups that, although still in the majority today, have been rapidly reducing in numbers and proportions in the Brazilian population. ${ }^{1}$ Thus, this program requires readjustment for this new group of elderly people, which needs different types of drugs.

Aging is associated with greater numbers of patients with chronic diseases. This, in turn, leads to increased drug consumption ${ }^{9}$ and increased frequency of significant adverse effects, drug interactions and polypharmacy. ${ }^{10}$ Elderly people have smaller volumes of water in their bodies, which leads to greater bioavailability of water-soluble drugs (for example, lithium and digoxin). However, lipid-soluble drugs like diazepam have a higher volume of distribution due to increased fat content in the body composition of this group. Other conditions that contribute towards uneven biodistribution of medicines among the elderly are the following: (1) plasma albumin concentration tends to be lower than in young adults, thereby lowering the binding capacity of drugs and resulting in increased plasma-free fractions and increased volume of distribution; and (2) progressive reduction in the capacity for renal excretion (due to the normal aging process and/ or chronic diseases like hypertension and diabetes mellitus), thereby prolonging the half-life of drugs and increasing the likelihood of adverse effects. ${ }^{11}$

From this viewpoint, there is a need to evaluate which drugs are safe and effective and which should be avoided for elderly individuals. Criteria such as Beers-Fick ${ }^{6}$ seek to provide warnings regarding groups of drugs that are potentially inappropriate for this age group.

A percentage of the population, usually without the financial resources to afford regular consumption of drugs, relies on government support programs to gain access to medicines. There is thus a need to add flexibility to these programs, in order to monitor current and future demographic shifts.

From our evaluation of the Farmácia Dose Certa program in São Paulo, we found that approximately $25.0 \%$ of the drugs available were potentially inappropriate for elderly individuals according to the BeersFick criteria. Although neither the present study nor the original papers by Beers ${ }^{5}$ and Fick et al. $^{6}$ had the aim of analyzing alternatives, we can make the observation that most of these drugs may be replaced with others that are more suitable for this age group.

This deserves attention, since certain medications that are usually prescribed for diseases that are common in old age, such as those with cardiovascular or central nervous system action, fulfill the criteria for inappropriateness according to Beers and Fick, yet form part of the program list.

This can be explained by the high prevalence of neurodegenerative diseases (such as Parkinson's disease and Alzheimer's disease) and mood disorders (i.e. depression and anxiety), ${ }^{12}$ which are associated with increased susceptibility to anticholinergic effects, i.e. sedation, falls or delirium. ${ }^{13}$

Some drugs included in the Beers-Fick criteria deserve additional comments. (1) amitriptyline presents anticholinergic effects and sedation, with level of evidence $=1 ;{ }^{6,14-17}$ (2) cimetidine has central nervous system side effects, including mental confusion, with level of evidence $=4{ }^{18-20}$ (3) diazepam has a long half-life, produces sedation and predisposes towards falls and fractures, with level of evidence $=2 ;^{6,21-23}$ (4) digoxin gives rise to renal clearance dysfunction, which may lead to increase toxicity risks, with level of evidence $=2 ;^{6,24-26}$ (5) fluoxetine has a long half-life, which leads to a risk of central nervous system overstimulation, sleep disorders and agitation, with level of evidence $=5 \cdot{ }^{6,27}$ However, some studies have not shown any differences in adverse events, when comparing fluoxetine with other drugs, ${ }^{28-30}$; (6) methyldopa, which presents bradycardia and depression in the elderly, with level of evidence $=5.6,31,32$ However, some studies showed no differences in adverse events, when comparing methyldopa with other drugs ${ }^{33,34}(7)$ nifedipine presents hypotension and constipation, with level of evidence $=2 ;^{6,35-37}(8)$ thioridazine is a typical neuroleptic with great potential for extrapyramidal and central nervous system symptoms, with level of evidence $=5 ;^{6,38}(9)$ promethazine has anticholinergic effects, with level of evidence $=3 ;^{38,39}$ and (10) ferrous sulfate, which at doses greater than $325 \mathrm{mg} /$ day may increase constipation, with level of evidence $=5 .^{6}$

Although most of these drugs may be replaced by more suitable ones for this age group, there are some classes of drugs with few options for physicians, such as antiulcer drugs and drugs for allergies. For example, antiulcer drugs (in this case, cimetidine) may be replaced by proton pump inhibitors (i.e. omeprazole, pantoprazole and lansoprazole, among others). Similarly, drugs for allergies (in this case promethazine) could be replaced by fexofenadine or loratadine. Drugs for treating diseases with high prevalence among the elderly that are often difficult to control, such as hypertension and depression, also have significant limitations regarding prescription, because of the high numbers of them that are deemed inappropriate according to these criteria.

Although not on the list of Beers-Fick criteria, other drugs such as biperiden (cognitive and balance problems), ${ }^{40}$ clonazepam (sleepiness and decreased reflexes), ${ }^{41}$ diclofenac sodium (gastrointestinal bleeding and decreased glomerular filtration rate), ${ }^{42}$ glibenclamide (prolonged hypoglycemia), ${ }^{43}$ nitrazepam (fall risk, ${ }^{44}$ disorientation, postural hypotension and cognitive dysfunction ${ }^{45}$ ), imipramine (orthostatic hypotension and falls ${ }^{46}$ ), haloperidol (tardive dyskinesia ${ }^{47}$ ) and lithium (prolonged half-life due to changes in renal function with higher risk of toxic levels ${ }^{48}$ ) are available on the list of the Farmácia Dose Certa program. In view of the effects that have been observed with the use of these drugs, they should be used with caution among this age group.

At no time did we question the scope and quality of the program, which has distributed more than 14 billion drug doses since its inception. Furthermore, the Farmácia Dose Certa program is supposed to cover most of the needs of the general population. However, if the program were better adapted to the pharmacological aspects of aging, 
the risks of drug interactions, falls, mental confusion and excessive sedation among elderly people would be reduced. Similarly, studies have shown that the use of potentially inappropriate medication increases healthcare spending ${ }^{49}$ and may lead to higher rates of hospitalization and mortality. ${ }^{50}$ Therefore, such medications should be replaced by safer ones. ${ }^{51}$

Certain limitations to the present study need to be mentioned. First, we used the Beers-Fick criteria. Although these are among the most widely used criteria for research, they may not represent or agree with the opinions of some specialists. In order to minimize this bias and help prescribing physicians, we decided to include the levels of evidence for each drug included. Second, the use of these criteria to assess the distribution of free drugs has rarely been addressed in the medical literature. This raises new questions, such as whether there would be good results in interventional studies, when comparing outcomes before and after these changes.

According to Lau et al., ${ }^{50}$ studies on the subject are needed in order to expand the acceptability of these criteria among public health experts, facilitate medical education and prescriptions for the elderly, and even to facilitate drug regulation.

\section{CONCLUSION}

In summary, this study points towards the need to revise the Farmácia Dose Certa program, in order to cover older consumers. This can be done through the introduction of new drugs or through a new list that is specific for the population over 60 years of age.

\section{REFERENCES}

1. Brasil. Ministério do Planejamento, Orçamento e Gestão. Instituto Brasileiro de Geografia e Estatística. Censo Demográfico 2000: características da população e dos domicílios: resultados do universo. Rio de Janeiro: IBGE; 2000. Available from: http://www.ibge.gov. br/home/estatistica/populacao/censo2000/default.shtm. Accessed in 2010 (Sep 15).

2. Wong LLR, Carvalho JA. 0 rápido processo de envelhecimento populacional do Brasil: sérios desafios para as políticas públicas [The rapid process of aging in Brazil: serious challenges for public policies]. Rev Bras Estud Popul. 2006;23(1):5-26.

3. Flores LM, Mengue SS. Uso de medicamentos por idosos na região sul do Brasil [Drug use by the elderly in Southern Brazil]. Rev Saúde Pública = J Public Health. 2005;39(6):924-9.

4. Nóbrega OT, Karnikowski MGO. A terapia medicamentosa no idoso: cuidados na medicação [Pharmacotherapy in the elderly: precautions with medication]. Ciênc Saúde Coletiva. 2005;10(2):309-13.

5. Beers MH. Explicit criteria for determining potentially inappropriate medication use by the elderly. An update. Arch Intern Med. 1997;157(14):1531-6.

6. Fick DM, Cooper JW, Wade WE, et al. Updating the Beers criteria for potentially inappropriate medication use in older adults: results of a US consensus panel of experts. Arch Intern Med. 2003;163(22):2716-24.

7. Brasil. Ministério da Saúde. Secretaria de Ciência, Tecnologia e Insumos Estratégicos. Departamento de Assistência Farmacêutica e Insumos Estratégicos. Relação nacional de medicamentos essenciais. Rename. $6^{\text {a }}$ ed. Brasília: Ministério da Saúde; 2009. Available from: http://portal.saude.gov.br/portal/arquivos/pdf/rename_2008.pdf. Accessed in 2010 (Sep 21)

8. Governo de São Paulo. Secretaria da Saúde. Programa Dose Certa. Lista de itens do Programa Dose Certa. Available from: http://www.saude.sp.gov.br/content/geral_acoes_assistencia_farmaceutica_programa_dose_certa.mmp. Accessed in 2010 (Sep 21).

9. Gorzoni ML, Lima CAC. Análise dos parâmetros clínicos de idosos internados em enfermaria de clínica médica [Analysis of clinical parameters of elderly inpatients in an internal medicine ward]. Rev Assoc Med Bras (1992). 1995;41(3):227-32.
10. Zhan C, Sangl J, Bierman AS, et al. Potentially inappropriate medication use in the community-dwelling elderly: findings from the 1996 Medical Expenditure Panel Survey. JAMA. 2001;286(22):2823-9.

11. Beyth RJ, Shorr RI. Uso de medicamentos. In: Duthie EH, Katz PR, editores. Geriatria prática. $3^{\text {a }}$ ed. Rio de Janeiro: Revinter; 2002. p. 37-46.

12. Ramos LR, Toniolo J, Cendoroglo MS, et al. Two-year follow-up study of elderly residents in S. Paulo, Brazil: methodology and preliminary results. Rev Saúde Pública = J Public Health. 1998;32(5):397-407.

13. Chaimowicz F, Ferreira TJXM, Miguel DFA. Use of psychoactive drugs and falls among older people living in a community in Brazil. Rev Saúde Pública = J Public Health. 2000;34(6):631-5.

14. Cohn CK, Shrivastava R, Mendels J, et al. Double-blind, multicenter comparison of sertraline and amitriptyline in elderly depressed patients. J Clin Psychiatry. 1990;51 Suppl B:28-33.

15. Kyle CJ, Petersen HE, Overø KF. Comparison of the tolerability and efficacy of citalopram and amitriptyline in elderly depressed patients treated in general practice. Depress Anxiety. 1998;8(4):147-53.

16. Altamura AC, Percudani M, Guercetti G, Invernizzi G Efficacy and tolerability of fluoxetine in the elderly: a double-blind study versus amitryptiline. Int Clin Psychopharmacol. 1989;4 Suppl 1:103-6.

17. Stuppaeck $\mathrm{CH}$, Geretsegger $\mathrm{C}$, Whitworth $\mathrm{AB}$, et al. A multicenter double-blind trial of paroxetine versus amitriptyline in depressed inpatients. J Clin Psychopharmacol. 1994;14(4):241-6.

18. Abdelfattah $\mathrm{A}$, Rayet $\mathrm{P}$, Carré $\mathrm{C}$. Effets neuro-psychiatriques de la cimétidine: à propos d'un cas [Neuro-psychiatric effects of cimetidine: a case report]. Ann Med Psychol (Paris) 1993;151(6):475-7.

19. Basavaraju NG, Wolf-Klein G, Silverstone FA, Libow LS. Cimetidine-induced mental confusion in elderly. NY State J Med. 1980;80(8):1287-8.

20. Kinnell HG, Webb A. Confusion associated with cimetidine. $\mathrm{Br}$ Med J. 1979;2(6202):1438.

21. Pomara N, Stanley B, Block R, et al. Increased sensitivity of the elderly to the central depressant effects of diazepam. J Clin Psychiatry. 1985;46(5):185-7.

22. Cumming RG, Miller JP, Kelsey JL, et al. Medications and multiple falls in elderly people: the St Louis OASIS study. Age Ageing. 1991;20(6):455-61.

23. Neutel $\mathrm{Cl}$, Hirdes JP, Maxwell CJ, Patten SB. New evidence on benzodiazepine use and falls: the time factor. Age Ageing. 1996;25(4):273-8.

24. Cusack B, Kelly J, O'Malley K, et al. Digoxin in the elderly: pharmacokinetic consequences of old age. Clin Pharmacol Ther. 1979;25(6):772-6.

25. Miura T, Kojima R, Sugiura Y, et al. Effect of aging on the incidence of digoxin toxicity. Ann Pharmacother. 2000;34(4):427-32.

26. Rich MW, McSherry F, Williford WO, Yusuf S; Digitalis Investigation Group. Effect of age on mortality, hospitalizations and response to digoxin in patients with heart failure: the DIG study. J Am Coll Cardiol. 2001;38(3):806-13.

27. Ferguson JM, Hill H. Pharmacokinetics of fluoxetine in elderly men and women. Gerontology. 2006;52(1):45-50.

28. Tollefson GD, Bosomworth JC, Heiligenstein JH, Potvin JH, Holman S. A double-blind, placebo-controlled clinical trial of fluoxetine in geriatric patients with major depression. The Fluoxetine Collaborative Study Group. Int Psychogeriatr. 1995;7(1):89-104.

29. Schöne W, Ludwig M. A double-blind study of paroxetine compared with fluoxetine in geriatric patients with major depression. J Clin Psychopharmacol. 1993;13(6 Suppl 2):34S$39 \mathrm{~S}$.

30. Newhouse PA, Krishnan KR, Doraiswamy PM, et al. A double-blind comparison of sertraline and fluoxetine in depressed elderly outpatients. J Clin Psychiatry. 2000;61(8):55968.

31. McKinney WT Jr, Kane FJ Jr. Depression with the use of alpha-methyldopa. Am J Psychiatry. 1967;124(1):80-1.

32. Fullerton AG, Morton-Jenkins D. Methyldopa and depression. $\mathrm{Br}$ Med J. 1963;1(5329):538-9.

33. VandenBurg MJ, Cooper WD, Woollard ML, Currie WJ, Bowker CH. Reduced peripheral vascular symptoms in elderly patients treated with alpha-methyldopa--a comparison with propranolol. Eur J Clin Pharmacol. 1984;26(3):325-9.

34. Patten SB, Love EJ. Can drugs cause depression? A review of the evidence. J Psychiatry Neurosci. 1993;18(3):92-102.

35. Bulpitt CJ, Connor M, Schulte M, Fletcher AE. Bisoprolol and nifedipine retard in elderly hypertensive patients: effect on quality of life. J Hum Hypertens. 2000;14(3):205-12.

36. Robertson DR, Waller DG, Renwick AG, George CF. Age-related changes in the pharmacokinetics and pharmacodynamics of nifedipine. Br J Clin Pharmacol. 1988;25(3):297-305.

37. Conlin PR, Elkins M, Liss C, et al. A study of losartan, alone or with hydrochlorothiazi- 
de vs nifedipine GITS in elderly patients with diastolic hypertension. J Hum Hypertens. 1998;12(10):693-9.

38. McClintock GH, LaReau RM, Watcharotone K, DeMaagd G. The initial examination of the efficacy of low-dose promethazine for the treatment of nausea and vomiting in the hospitalized elderly. Geriatr Nurs. 2010;31(2):115-22.

39. Scott J, Pache D, Keane G, Buckle H, O'Brien N. Prolonged anticholinergic delirium following antihistamine overdose. Australas Psychiatry. 2007;15(3):242-4.

40. Rigo JC, Rigo JFO, Faria BC, Santos VM. Demência reversível e quedas associadas ao biperideno [Reversible dementia and falls associated with biperiden]. Rev Psiquiatr Clín (São Paulo). 2006;33(1):24-7.

41. Hamra A, Ribeiro MB, Miguel OF. Correlação entre fratura por queda em idosos e uso prévio de medicamentos [Correlation between fractures resulting from falls and previous drug use]. Acta Ortop Bras. 2007;15(3):143-5.

42. Hughes GR. The problems of using NSAIDs in the elderly. Scand J Rheumatol Suppl. 1991;91:19-25.

43. Veitch PC, Clifton-Bligh RJ. Long-acting sulfonylureas--long-acting hypoglycaemia. Med J Aust. 2004;180(2):84-5.

44. Shats V, Kozacov S. [Falls in the geriatric department: responsibility of the care-giver and the hospital]. Harefuah. 1995;128(11):690-3, 743.

45. Evans JG, Jarvis EH. Nitrazepam and the elderly. Br Med J. 1972;4(5838):487.

46. Thayssen P, Bjerre M, Kragh-Sørensen P, et al. Cardiovascular effect of imipramine and nortriptyline in elderly patients. Psychopharmacology (Berl). 1981;74(4):360-4.

47. Jeste DV, Lacro JP, Palmer B, et al. Incidence of tardive dyskinesia in early stages of low-dose treatment with typical neuroleptics in older patients. Am J Psychiatry. 1999;156(2):309-11.

48. Tideiksaar R. Lithium therapy in the elderly. West J Med. 1978;129(2):147-8.

49. Fu AZ, Jiang JZ, Reeves JH, et al. Potentially inappropriate medication use and healthcare expenditures in the US community-dwelling elderly. Med Care. 2007;45(5):472-6.

50. Lau DT, Kasper JD, Potter DE, Lyles A, Bennett RG. Hospitalization and death associated with potentially inappropriate medication prescriptions among elderly nursing home residents. Arch Intern Med. 2005;165(1):68-74.

51. Laroche ML, Charmes JP, Bouthier F, Merle L. Inappropriate medications in the elderly. Clin Pharmacol Ther. 2009;85(1):94-7.

Conflict of interest: None

Sources of funding: None

Date of first submission: February 26, 2010

Last received: September 21, 2010

Accepted: September 30, 2010

Address for correspondence:

Giancarlo Lucchetti

Av. Juriti, 367 - apto 131

Vila Uberabinha - São Paulo (SP) - Brasil

CEP 04520-000

Tel. (+55 11) 5052-1298

E-mail: g.lucchetti@yahoo.com.br 